\title{
Comparison of Electrical and Thermal Performances of Glazed and Unglazed PVT Collectors
}

\author{
Jin-Hee Kim ${ }^{1}$ and Jun-Tae Kim ${ }^{2}$ \\ ${ }^{1}$ Green Home Energy Technology Research Center, Kongju National University, 275 Budae-Dong, Chungnam, \\ Cheonan 330-717, Republic of Korea \\ ${ }^{2}$ Department of Architectural Engineering, Kongju National University, 275 Budae-Dong, Chungnam, \\ Cheonan 330-717, Republic of Korea \\ Correspondence should be addressed to Jun-Tae Kim, jtkim@kongju.ac.kr \\ Received 4 April 2012; Accepted 15 August 2012 \\ Academic Editor: Christophe Menezo
}

Copyright (๑) 2012 J.-H. Kim and J.-T. Kim. This is an open access article distributed under the Creative Commons Attribution License, which permits unrestricted use, distribution, and reproduction in any medium, provided the original work is properly cited.

\begin{abstract}
Photovoltaic-thermal (PVT) collectors combine photovoltaic modules and solar thermal collectors, forming a single device that receives solar radiation and produces electricity and heat simultaneously. PVT collectors can produce more energy per unit surface area than side-by-side PV modules and solar thermal collectors. There are two types of liquid-type flat-plate PVT collectors, depending on the existence of glass cover over PV module: glass-covered (glazed) PVT collectors, which produce relatively more thermal energy but have lower electrical yield, and uncovered (unglazed) PVT collectors, which have relatively lower thermal energy with somewhat higher electrical performance. In this paper, the experimental performance of two types of liquid-type PVT collectors, glazed and unglazed, was analyzed. The electrical and thermal performances of the PVT collectors were measured in outdoor conditions, and the results were compared. The results show that the thermal efficiency of the glazed PVT collector is higher than that of the unglazed PVT collector, but the unglazed collector had higher electrical efficiency than the glazed collector. The overall energy performance of the collectors was compared by combining the values of the average thermal and electrical efficiency.
\end{abstract}

\section{Introduction}

The overall efficiency of a PV system, which has relatively lower efficiency among renewable energy systems, depends on the efficiency of the solar cells and the PV modules themselves. Today, in general, silicon-based PV modules have an electrical efficiency of about $12 \sim 16 \%$ under standard test condition (STC: air mass 1.5, irradiation intensity $1000 \mathrm{~W} / \mathrm{m}^{2}$, and cell temperature $25^{\circ} \mathrm{C}$ ). Furthermore, the efficiency of PV modules of a Building-Integrated Photovoltaic (BIPV) System can be lowered due to the increase of the PV module temperature.

The photovoltaic/thermal (PVT) concept offers an opportunity to increase overall efficiency by the use of waste heat generated in the PV module of the BIPV system. It is well known that PVT systems enhance PV efficiency by PV cooling, where PV cooling may be achieved by circulating a colder fluid, water, or air, at the underside of the PV module.
Among the various types of PVT systems, liquid-type PVT collectors combine a photovoltaic module and a solar thermal collector, forming a single device that converts solar energy into electricity and heat simultaneously. The heat from PV modules can be removed in order to enhance the electrical performance of the PV module; this heat can be converted into useful thermal energy. As a result, PVT collectors can generate more solar energy per unit surface area than can side-by-side photovoltaic modules and solar thermal collectors.

Since the early 1970s, much progress has been achieved in the research and development of PVT systems. In a study focused on a liquid type PVT collector, Wolf [1] analyzed the heating performance in a US residence using a liquidtype flat-plate PVT collector and concluded that it was technically feasible. Kern and Russell eliminated heat on the roof or wall of a BIPV, thus initiating theoretical and experimental research using air or water [2]. This approach 


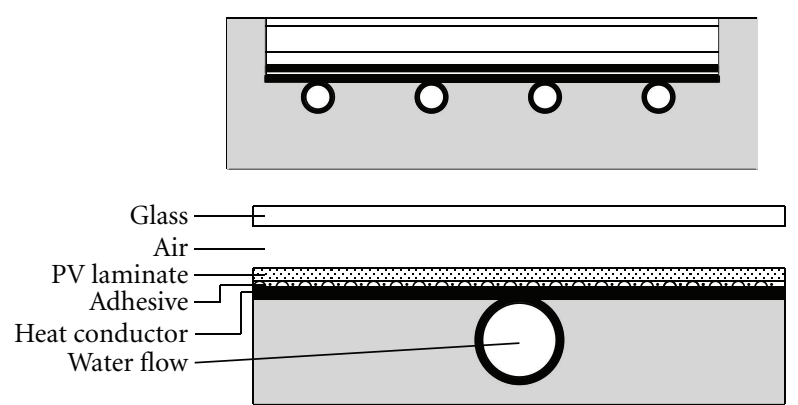

FIgUre 1: Sectional view of a glazed PVT collector.

began with technical and construction issues derived from a BIPV system combined with a roof-integrated collector. In addition, other studies [3] presented a theoretical model of a PVT system utilizing then-current solar collectors. Building on these studies, Raghuraman [4], Cox III and Raghuraman [5], Braunstein and Kornfeld [6], and Lalović et al. [7] carried out studies of PVT systems based on flattype collectors.

Bergene and Løvvik [8] thoroughly analyzed the electrical and thermal efficiencies of a liquid-type PVT system and the energy conversion between different factors. Sopian et al. [9] compared the performances under normal conditions of single- and double-PVT collectors. They concluded that the double-pass-type-PVT collector showed better performance regarding the cooling effect of a solar cell. In another study $[10,11]$, experimental and theoretical performances were examined with respect to a liquid-type flat-plate PVT collector. Fujisawa and Tani [12] evaluated the effective energy of a PVT collector depending on the existence of a glass cover. One study [13] involved PVT collectors with various designs, such as the absence of a glass cover, use of a single cover, and incorporation of a double cover; these were designed and their long-term performance was calculated under normal conditions. Various types of liquid PVT collectors have also been suggested, such as a channeltype PVT collector [14], a PVT collector with polymer absorbers [15], and thermosyphon PVT collectors [16-18]. Glazed and unglazed PVT collectors were compared by Tripanagnostopoulos et al. [19].

Various designs of liquid type PVT systems have since been proposed, and the theoretical and experimental performances of PVT systems have been evaluated. In addition, research has been actively carried out on PVT systems linked to conventional heating and cooling facilities. Moreover, economic feasibility studies have been presented, including a calculation of the payback period and the effectiveness of PVT systems.

In general, in the case of liquid type PVT collectors, two types can be distinguished: glazed PVT collectors (Figure 1), which produce more heat but have slightly lower electrical yield, and unglazed PVT collectors (Figure 2), which produce relatively less thermal energy but show somewhat higher electrical performance.

Glazed PVT collectors are very similar in appearance to flat-plate solar thermal collectors, consisting of a PV-covered absorber in an insulated collector box with a glass cover. This

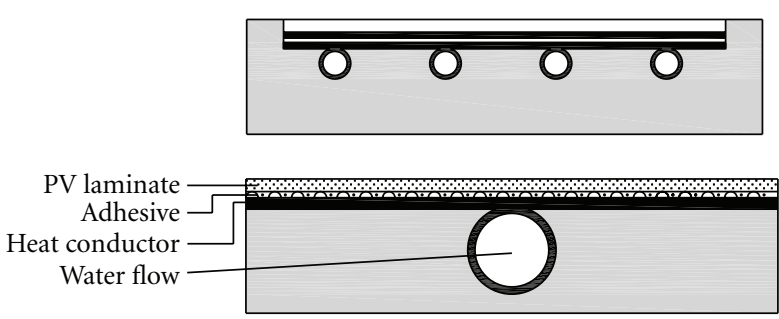

FIgURE 2: Sectional view of an unglazed PVT collector.

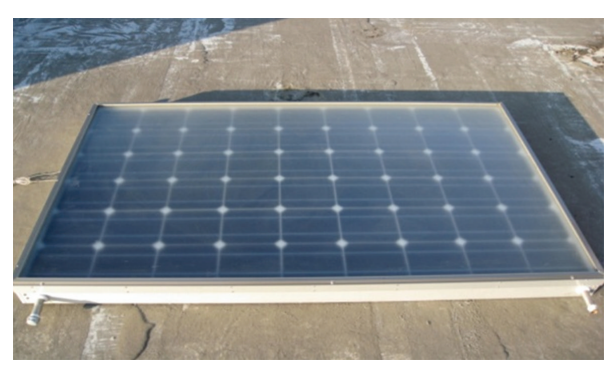

FIgURE 3: Glazed PVT collector.

glass-covered insulation leads to high thermal efficiency with some reduction of electrical efficiency due to solar radiation reflection and the increase in the PV module temperature introduced by the glass cover. On the other hand, unglazed PVT collectors are more similar to regular PV panels. They consist of a PV-covered absorber with no additional glass cover. The configuration without a glass cover results in lower thermal efficiency; hence, unglazed PVT collectors deliver relatively low thermal energy with higher electrical efficiency due to the PV module cooling effect. The electrical efficiency of an unglazed PVT collector is higher than that of a glazed PVT collector and is even higher than that of regular PV panels due to the PV cooling effect. However, the thermal efficiency of the unglazed type is lower than that of the glazed PVT collector due to higher heat loss from the collector surfaces.

The aim of this study is to compare the electrical and thermal performances of glazed (Figure 1) and unglazed collectors (Figure 2). In this paper, two different types of liquid-type PVT collectors were fabricated, and the thermal and electrical performance levels of these prototypes were measured outdoors. The results were then compared.

\section{PVT Collector Design and Manufacture}

The liquid-type flat plate PVT collectors used for this study are shown in Figures 3 and 4. The PVT collectors consist of PV modules in combination with water heat extraction units made from copper sheet and tube. The glazed PVT collector has a low-iron glazing cover of $4 \mathrm{~mm}$ thickness with air space of $20 \mathrm{~mm}$ and is thermally protected with $70 \mathrm{~mm}$ glass-wool thermal insulation. A copper sheet and tube absorber was attached at the PV module back side by thermal conduction adhesive. The PV modules used for the collectors are $200 \mathrm{~W}_{\mathrm{p}}$ pc-si PV modules and have electrical efficiency of $14 \%$ under STC. The specifications are shown 
TABLE 1: PV module specifications.

\begin{tabular}{lc}
\hline Cell type & Polycrystalline silicon \\
Maximum power & $200 \mathrm{~W}$ \\
Maximum voltage & $25.8 \mathrm{~V}$ \\
Maximum current & $7.75 \mathrm{~A}$ \\
Shot current & $8.65 \mathrm{~A}$ \\
Open voltage & $33.21 \mathrm{~V}$ \\
Size & $1454 * 974 * 38 \mathrm{~mm}$ \\
\hline
\end{tabular}

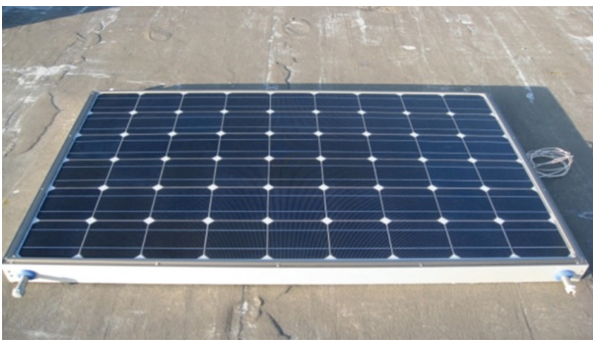

Figure 4: Unglazed PVT collector.

in Table 1. The configuration of unglazed PVT collector was the same as that of the glazed PVT collector except for the incorporation of the glass cover in the latter.

\section{Experiment}

The two different types of PVT collector were tested at solar radiation above $790 \mathrm{~W} / \mathrm{m}^{2}$ and a flow rate of $0.02 \mathrm{~kg} / \mathrm{sm}^{2}$, based on ASHRAE standard 93-77 [20] and PVT performance measurement guidelines of ECN (Energy Research Centre of The Netherlands) [21]. The electrical and thermal performance measurements were carried out under a quasistationary condition in an outdoor environment (Figure 5).

Several experimental devices were installed to measure the data related to the thermal and electrical performances of the PVT collector.

The PVT collector was tested at steady state conditions to determine its electrical and thermal performances for various inlet operating temperatures. Inlet and outlet temperatures of PVT collector were monitored and measured using a RTD-type thermocouple with a measurement error of $\pm 0.1 \%$ at $0^{\circ} \mathrm{C}$. The inlet temperature of PVT collector was controlled by set temperature equipment and the inlet temperature remained constant, while an outlet temperature varied. Also, the ambient temperature was measured by a T-type thermocouple with measurement error of $\pm 0.2^{\circ} \mathrm{C}$. Antifreezing liquid was supplied to the PVT collector at a uniform flow rate of $0.02 \mathrm{~kg} / \mathrm{sm}^{2}$ from a pump. The mass flow rate at the inlet pipe of the PVT collector was measured by an electronic flow meter. The normal quantity of solar radiation on the PVT collector surface was measured by Eppley pyranometer installed parallel to the collector plane.

Electrical loading resistors and a power meter were installed in order to measure the electrical performance (DC current-voltage and power) of the PVT. All of data related to the thermal and electrical performances of the PVT collector were monitored and recorded at $10 \mathrm{~s}$ intervals through a data acquisition system.

\section{Results and Discussion}

With the results of the outdoor test of the PVT collectors, the thermal and electrical performances were analyzed and the experimental results for the two different types of PVT collector were compared.

4.1. Thermal Performance. The thermal efficiency is determined as a function of the solar radiation $(G)$, the input fluid temperature $\left(T_{i}\right)$, and the ambient temperature $\left(T_{a}\right)$. The steady state efficiency is calculated by the following equation:

$$
\eta_{\mathrm{th}}=\frac{\dot{m} C_{p}\left(T_{o}-T_{i}\right)}{\left(A_{\mathrm{PVT}} G\right)}
$$

where $\eta_{\mathrm{th}}$ is the thermal efficiency [-]; $A_{\text {PVT }}$ is the collector area $\left[\mathrm{m}^{2}\right] ; T_{o}$ is the collector outlet temperature $\left[{ }^{\circ} \mathrm{C}\right] ; T_{i}$ is the collector inlet temperature $\left[{ }^{\circ} \mathrm{C}\right] ; \dot{m}$ is the mass flow rate $[\mathrm{kg} / \mathrm{s}] ; C_{p}$ is the specific heat $[\mathrm{J} / \mathrm{kg} \mathrm{K}] ; G$ is the irradiance on the collector surface $\left[\mathrm{W} / \mathrm{m}^{2}\right]$.

The thermal efficiency $\left(\eta_{\mathrm{th}}\right)$ of the PVT collectors was conventionally calculated as a function of the ratio $\Delta T / G$ where $\Delta T=T_{i}-T_{a}$.

Here, $T_{i}$ and $T_{a}$ are the PVT collector inlet temperature and the ambient temperature, respectively, and $G$ is the solar radiation in the collector plane. Hence, $\Delta T$ is a measurement of the temperature difference between the collector and its surroundings, relative to the solar radiation. The thermal efficiency $\eta_{\text {th }}$ is then expressed as

$$
\eta_{\mathrm{th}}=\eta_{0}-\alpha_{1}\left(\frac{\Delta T}{G}\right)
$$

where $\eta_{0}$ is the thermal efficiency at zero-reduced temperature, and $\alpha_{1}$ is the heat loss coefficient.

With the measurement results of the two different types of PVT collector, the thermal performance can be expressed as presented in Figure 6. Thermal efficiencies of the glazed and unglazed PVT collectors can be expressed with the relational expressions $\eta_{\mathrm{th}}=0.51-5.36(\Delta T / G)$ and $\eta_{\mathrm{th}}=$ $0.45-10.15(\Delta T / G)$, respectively. Thus, the thermal efficiencies $\left(\eta_{0}\right)$ at zero-reduced temperature are 0.51 and 0.45 , respectively, thus showing that the glazed PVT collector efficiency is higher than that of the unglazed PVT collector. Also, the heat loss coefficient $\left(\alpha_{1}\right)$ is $-5.36 \mathrm{~W} / \mathrm{m}^{2}{ }^{\circ} \mathrm{C}$ and $-10.15 \mathrm{~W} / \mathrm{m}^{2}{ }^{\circ} \mathrm{C}$, respectively: the unglazed PVT collector provided approximately twofold better performance than the glazed PVT collector. The average thermal efficiency of the glazed and unglazed PVT collectors is about $38 \%$ and $24 \%$, respectively, at the same outdoor conditions.

4.2. Electrical Performance. The electrical efficiency depends mainly on the incoming solar radiation and the temperature 


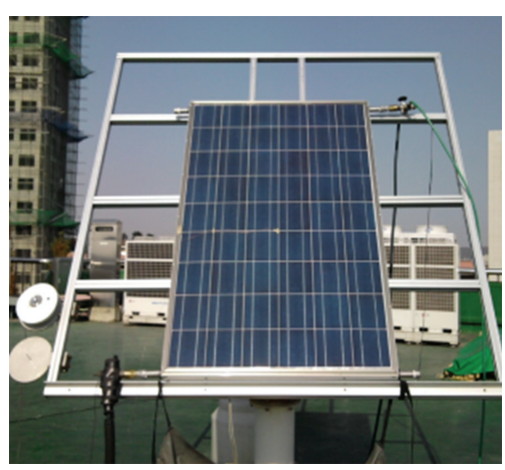

(a)

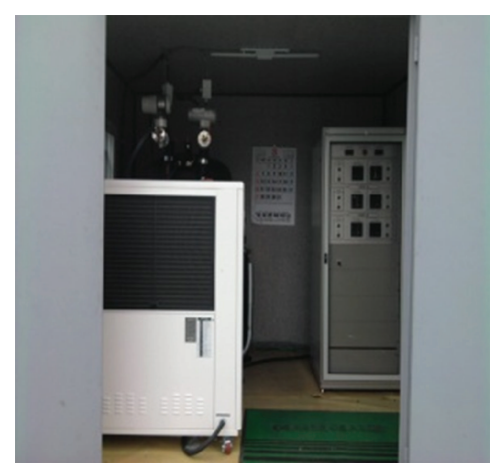

(b)

FIGURE 5: View of PVT collector (a) evaluated in the experiment and performance measurement equipment for the PVT collector (b).

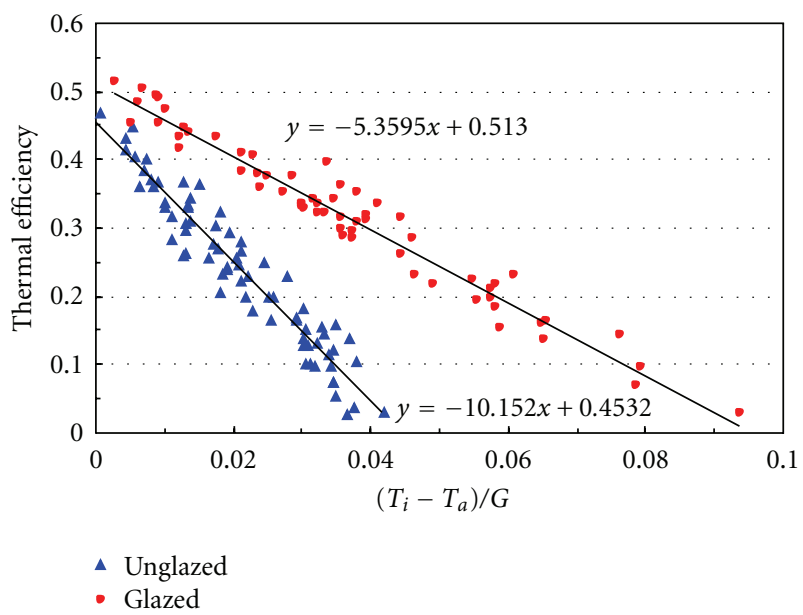

Figure 6: Glazed and unglazed PVT collectors thermal efficiency.

of PV module that was used in the tested PVT collectors and is calculated with the following:

$$
\eta_{\mathrm{el}}=\frac{I_{m} V_{m}}{A_{\mathrm{PVT}} G}
$$

where $I_{m}$ and $V_{m}$ are the current and the voltage of the PV module operating at maximum power.

The electrical efficiencies of the glazed and unglazed PVT collector at the outdoor conditions are shown in Figure 7. The performance of the glazed and unglazed PVT collector can be expressed with the relational expressions $\eta_{\mathrm{el}}=0.108-$ $0.15(\Delta T / G)$ and $\eta_{\mathrm{el}}=0.123-0.22(\Delta T / G)$, respectively. Thus, the electrical efficiency $\left(\eta_{0}\right)$ at zero reduced temperature is 0.108 and 0.123 , respectively, and the electricity loss coefficient is -0.22 and -0.15 , respectively. From these results, it was analyzed that the unglazed PVT collector presents about 14\% higher electrical efficiency, compared to the glazed PVT collector. This difference appears to be significant as about it reflects roughly a $1.5 \%$ difference in the PV modules' electrical efficiency. It is obvious that while the unglazed PVT collector displayed poorer thermal performance at zero reduced temperature, it performs better in terms of generating electricity. The average electrical

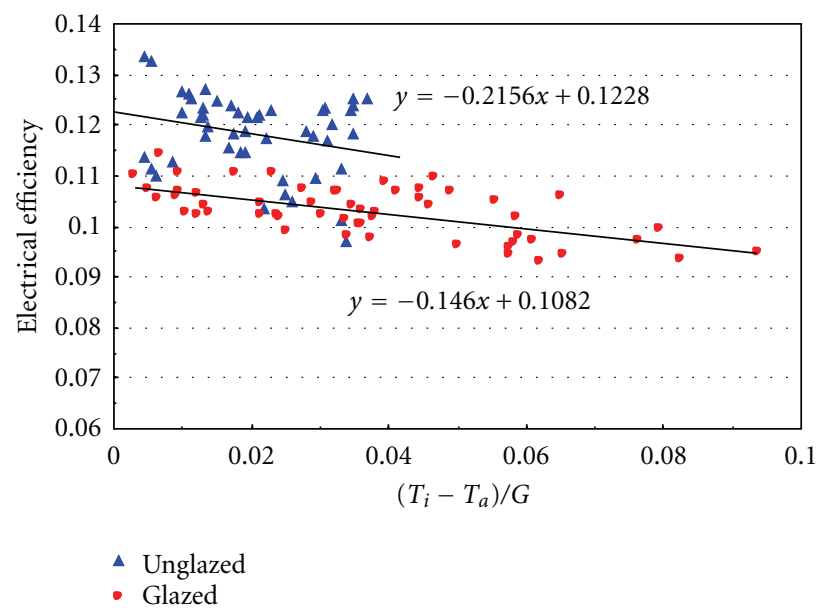

FIGURE 7: Glazed and unglazed PVT collectors electrical efficiency.

efficiencies of the glazed and unglazed PVT collectors are about $10.3 \%$ and $11.8 \%$, respectively.

The PV module temperature depends on the cooling effects of the PV module by the fluid in the PVT collectors. The electrical performance was analyzed as a function of the PVT inlet fluid temperature and solar radiation. The DC power generation of the PVT collectors as a function of solar radiation and inlet fluid temperature is shown in Figures 8 and 9.

For the glazed PVT collector, the DC power increased according to an increase of solar radiation, and the DC power generation improved with lower inlet fluid temperature. These results indicate that the inlet fluid temperature of the PVT collector affected the PV module temperature. In the case of unglazed PVT collector, the same result was also found. However, the DC power generation of the unglazed collector appears to be less influenced by solar radiation, compared to the glazed PVT.

Furthermore, the electrical performance was analyzed and compared as a function of each PVT inlet fluid temperature and solar radiation.

In Figures 10 and 11, the DC power generation and electrical efficiency of the PVT collectors as a function of 


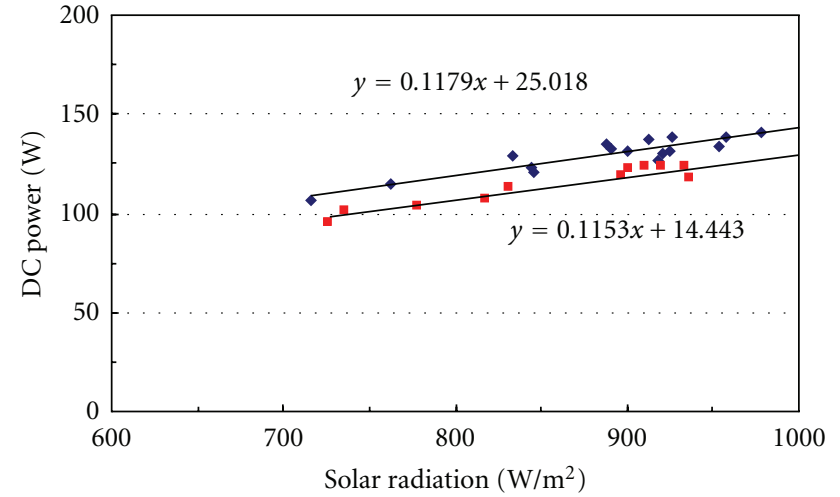

- $30-40^{\circ} \mathrm{C}$

- $60-80^{\circ} \mathrm{C}$

FIGURE 8: Electrical power of the glazed PVT collector as a function of solar radiation and fluid temperature.

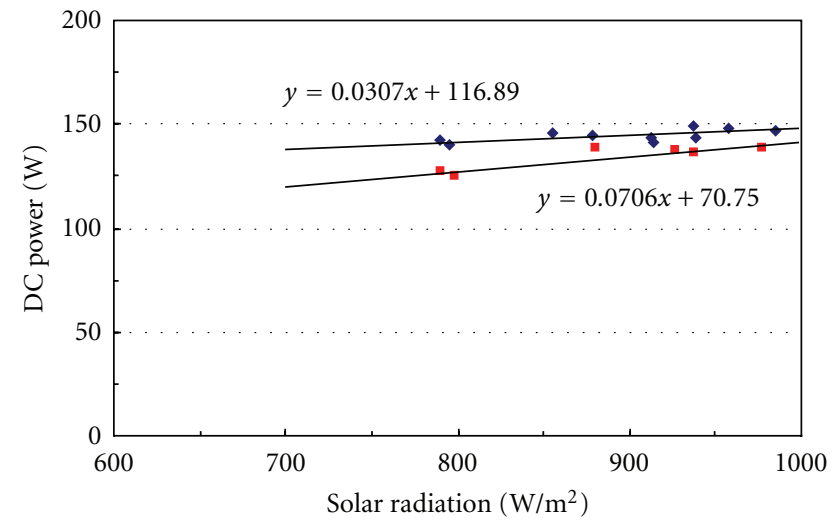

- $30-40^{\circ} \mathrm{C}$

- $40-60^{\circ} \mathrm{C}$

FIGURE 9: Electrical power of the unglazed PVT collector as a function of solar radiation and temperature.

the inlet fluid temperature are shown. For the glazed and unglazed PVT collectors, the electrical efficiency decreased according to increased inlet fluid temperature in both cases. The unglazed PVT collector presents higher electrical efficiency compared to the glazed PVT collector at the same inlet temperature condition of the PVT collector. The glazed type tends to lose less heat due to the incorporation of the glass cover as compared to the unglazed type. Therefore, the glazed type can maintain higher temperature of the fluid coming into the collector, which affects the PV module temperature.

In addition, in the case of the glazed collector, reflection and absorption losses of solar radiation at the glass cover reduce its electrical performance. As a result, the unglazed PVT collector provides better electrical performance than that of the glazed PVT collector.

The DC power generation and electrical efficiency of the PVT collectors as a function of solar radiation are shown in Figures 12 and 13. For the glazed and unglazed PVT

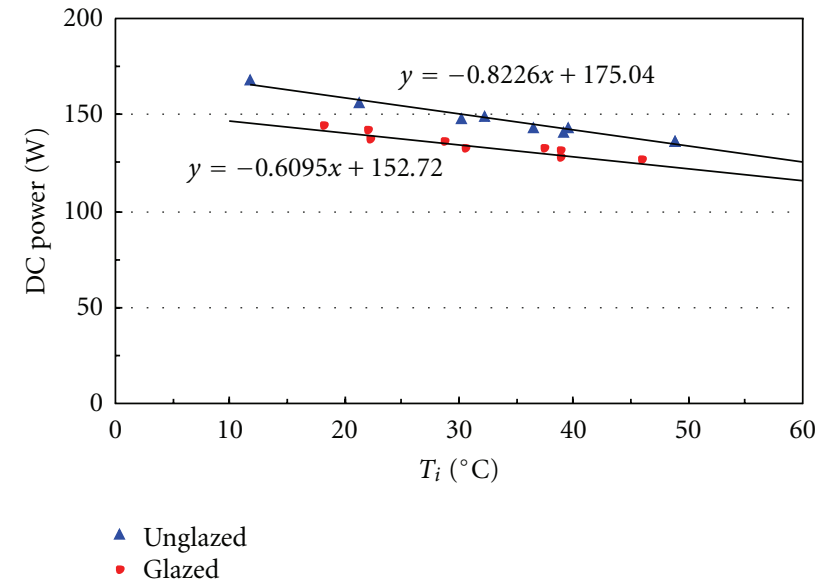

Figure 10: Electrical power of the glazed and unglazed PVT collectors as a function of temperature (solar radiation $950 \mathrm{~W} / \mathrm{m}^{2}$ ).

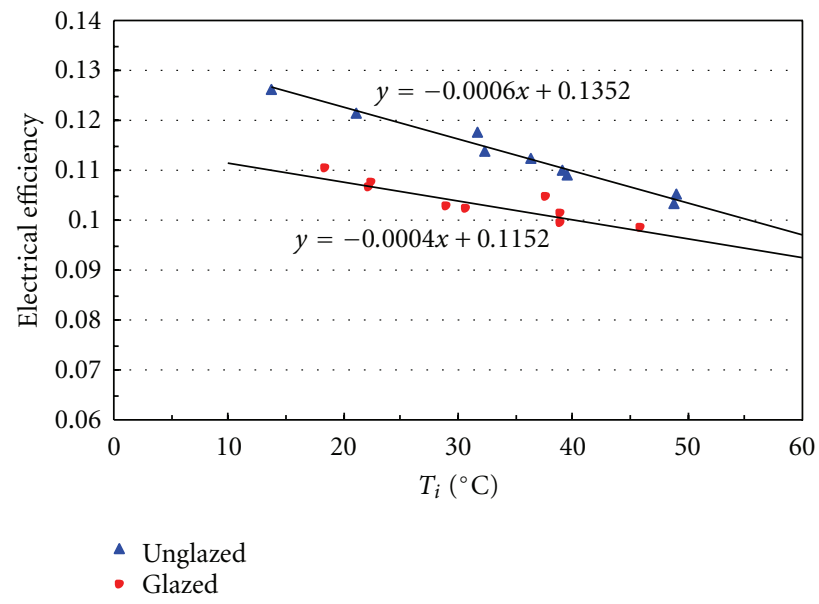

FIGURE 11: Electrical efficiency of the glazed and unglazed PVT collectors as a function of fluid inlet temperature (solar radiation $\left.950 \mathrm{~W} / \mathrm{m}^{2}\right)$.

collectors, the DC power increased in both cases according to increased solar radiation; on the other hand, their electrical efficiency decreased. These results may be due to increased PV module temperature.

\section{Conclusion}

This paper analyzed the thermal and electrical performance of two types of PVT collectors, a liquid-glazed type and -unglazed type. The results show that the thermal efficiency of the Glazed PVT collector is $14 \%$ higher than that of the unglazed collector, and the unglazed PVT collector had, on average, approximately $1.4 \%$ higher electrical efficiency than the glazed PVT collector.

The overall energy performance of the collectors can be compared by combining the values of the average thermal and electrical efficiencies: the glazed PVT collector presents a value of $48.4 \%$ and the unglazed PVT collector gives a value of $35.8 \%$. Even though the overall performance of the 


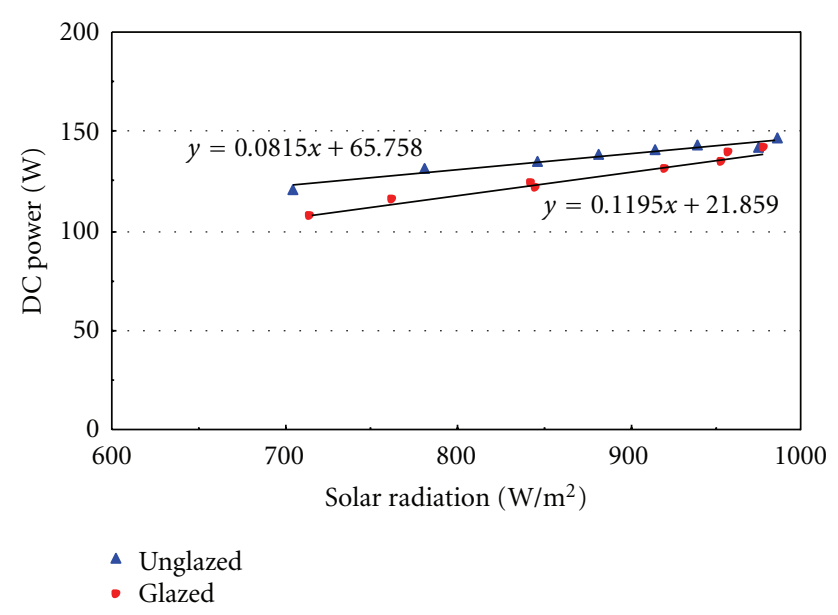

Figure 12: Electrical power of the glazed and unglazed PVT collectors as a function of solar radiation $\left(T_{i}=40^{\circ} \mathrm{C}\right)$.

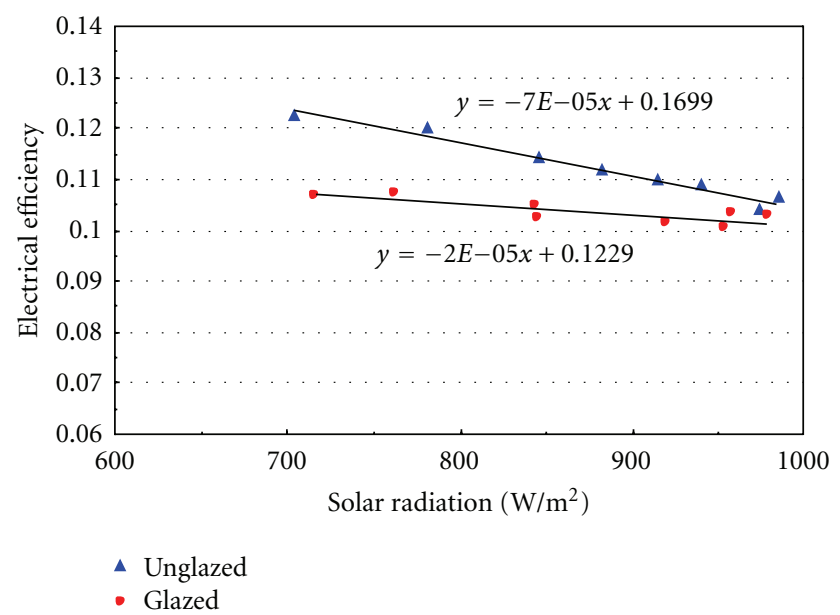

FIgURE 13: Electrical efficiency of the glazed and unglazed PVT collectors as a function of solar radiation $\left(T_{i}=40^{\circ} \mathrm{C}\right)$.

glazed is $12.6 \%$ higher than that of the unglazed collector, it cannot be concluded that the former is superior to the latter: the selection of an optimal configuration will depend on the overall cost efficiency and energy balance of the systems. Also, it is clear that the electrical performance of PVT collectors depends on the cooling effect of the PV module from the PVT inlet fluid temperature and solar radiation.

\section{Acknowledgments}

This work was supported by the Priority Research Centers Program through the National Research Foundation of Korea (NRF) funded by the Ministry of Education, Science and Technology (no. 2009-0093825) and a Human Resources Development of the Korea Institute of Energy Technology Evaluation and Planning Grant (no. 20114010203040) funded by the Korean Ministry of Knowledge Economy.

\section{References}

[1] M. Wolf, "Performance analyses of combined heating and photovoltaic power systems for residences," Energy Conversion, vol. 16, no. 1-2, pp. 79-90, 1976.

[2] Y. Tripanagnostopoulos, T. Nousia, M. Souliotis, and P. Yianoulis, "Hybrid photovoltaic/thermal solar systems," Solar Energy, vol. 72, no. 3, pp. 217-234, 2002.

[3] S. D. Hendrid, "Evaluation of combined photovoltaic/thermal collectors," in Proceedings of the ISES International Congress, pp. 1865-1869, Atlanta, Ga, USA, March, 1979.

[4] P. Raghuraman, "Analytical predictions of liquid and air photovoltaic/thermal, flat-plate collector performance," Journal of Solar Energy Engineering, vol. 103, no. 4, pp. 291-298, 1981.

[5] C. H. Cox III and P. Raghuraman, "Design considerations for flat-plate-photovoltaic/thermal collectors," Solar Energy, vol. 35, no. 3, pp. 227-241, 1985.

[6] A. Braunstein and A. Kornfeld, "On the development of the solar photovoltaic and thermal (pvt) collector," IEEE Transactions on Energy Conversion, vol. EC-1, no. 4, pp. 31-33, 1986.

[7] B. Lalović, Z. Kiss, and H. Weakliem, "A hybrid amorphous silicon photovoltaic and thermal solar collector," Solar Cells, vol. 19, no. 2, pp. 131-138, 1986.

[8] T. Bergene and O. M. Løvvik, "Model calculations on a flatplate solar heat collector with integrated solar cells," Solar Energy, vol. 55, no. 6, pp. 453-462, 1995.

[9] K. Sopian, K. S. Yigit, H. T. Liu, S. Kakaç, and T. N. Veziroglu, "Performance analysis of photovoltaic thermal air heaters," Energy Conversion and Management, vol. 37, no. 11, pp. 16571670, 1996.

[10] H. P. Garg, R. K. Agarwal, and J. C. Joshi, "Experimental study on a hybrid photovoltaic-thermal solar water heater and its performance predictions," Energy Conversion and Management, vol. 35, no. 7, pp. 621-633, 1994.

[11] H. P. Garg and R. K. Agarwal, "Some aspects of a PV/T collector/forced circulation flat plate solar water heater with solar cells," Energy Conversion and Management, vol. 36, no. 2, pp. 87-99, 1995.

[12] T. Fujisawa and T. Tani, "Annual exergy evaluation on photovoltaic-thermal hybrid collector," Solar Energy Materials and Solar Cells, vol. 47, no. 1-4, pp. 135-148, 1997.

[13] D. W. Vries, Design of a photovoltaic/thermal combi-panel [Ph.D. thesis], Eindhoven Technical University, 1998.

[14] H. A. Zondag, D. W. de Vries, W. G. J. van Helden, R. J. C. van Zolingen, and A. A. van Steenhoven, "The yield of different combined PV-thermal collector designs," Solar Energy, vol. 74, no. 3, pp. 253-269, 2003.

[15] B. Sandnes and J. Rekstad, "A photovoltaic/thermal (PV/T) collector with a polymer absorber plate. Experimental study and analytical model," Solar Energy, vol. 72, no. 1, pp. 63-73, 2002.

[16] H. P. Garg, R. K. Agarwal, and J. C. Joshi, "Experimental study on a hybrid photovoltaic-thermal solar water heater and its performance predictions," Energy Conversion and Management, vol. 35, no. 7, pp. 621-633, 1994.

[17] T. T. Chow, A. L. S. Chan, K. F. Fong, W. C. Lo, and C. L. Song, "Energy performance of a solar hybrid collector system in a multistory apartment building," Proceedings of the Institution of Mechanical Engineers A, vol. 219, no. 1, pp. 1-11, 2005.

[18] T. T. Chow, W. He, J. Ji, and A. L. S. Chan, "Performance evaluation of photovoltaic-thermosyphon system for subtropical climate application," Solar Energy, vol. 81, no. 1, pp. 123-130, 2007. 
[19] Y. Tripanagnostopoulos, T. Nousia, M. Souliotis, and P. Yianoulis, "Hybrid photovoltaic/thermal solar systems," Solar Energy, vol. 72, no. 3, pp. 217-234, 2002.

[20] American Society of Heating, Refrigerating and Air Conditioning Engineers (ASHRAE), Methods of Testing To Determine the Thermal Performance of Solar Collectors, ASHRAE, 1991.

[21] H. Zondag, N. Borg, and W. Eisenmann, D8-6: PVT Performance Measurement Guidelines, ECN Editor, Petten, The Netherlands, 2005. 


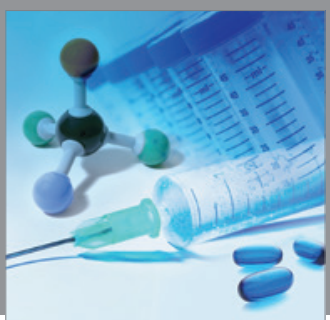

International Journal of

Medicinal Chemistry

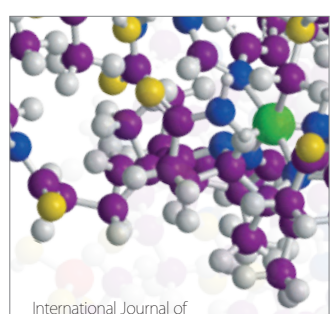

Carbohydrate Chemistry

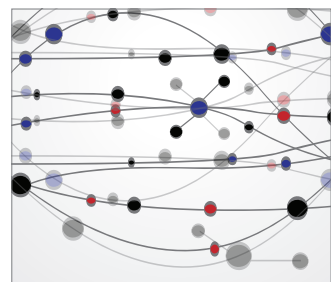

The Scientific World Journal
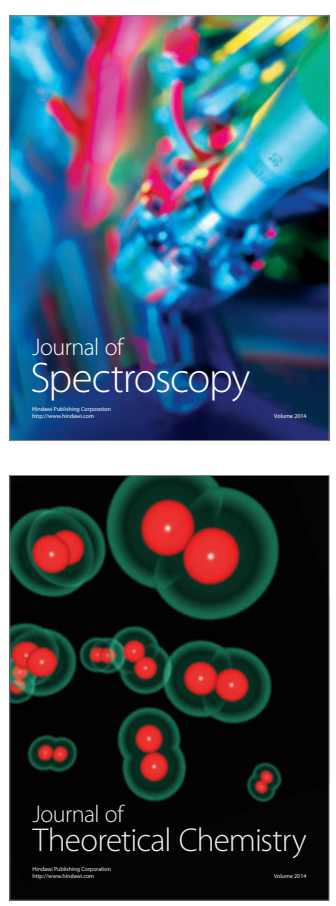
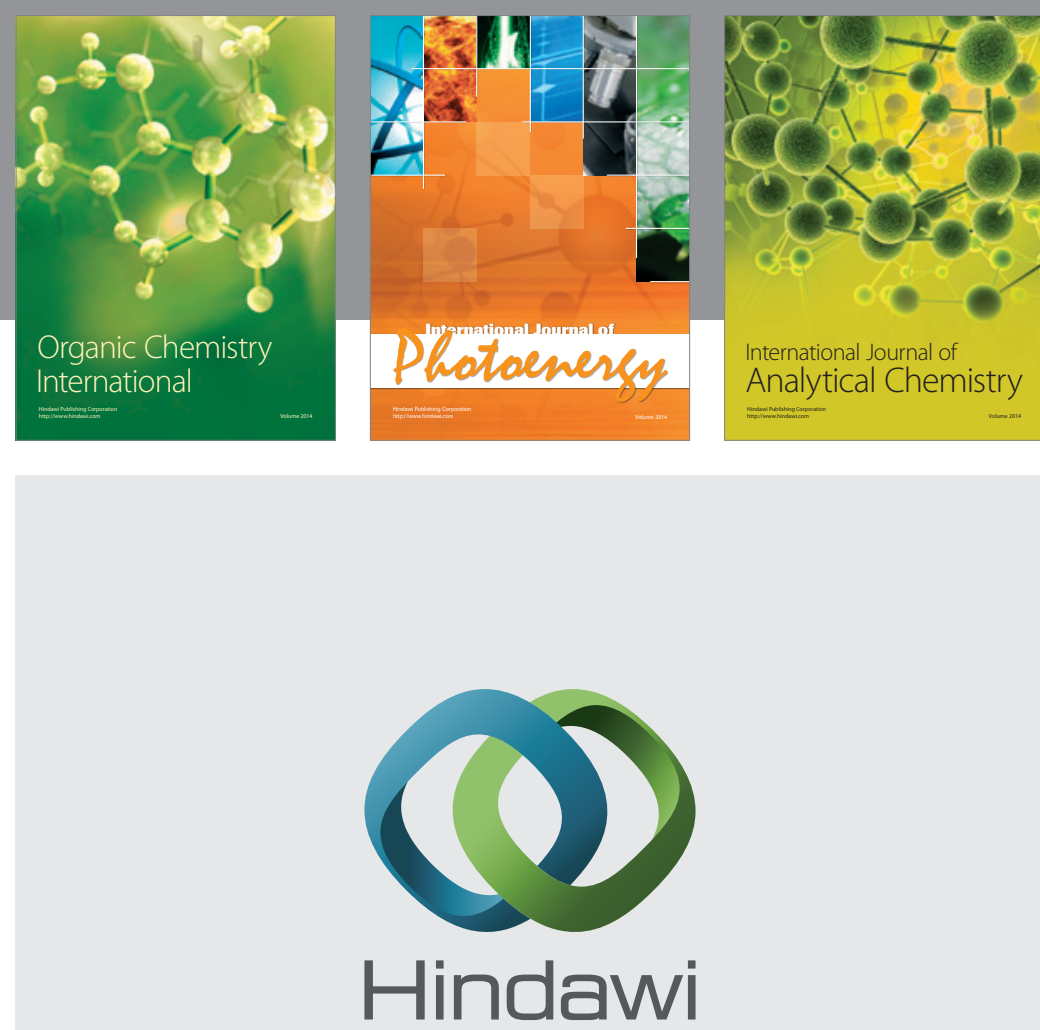

Submit your manuscripts at

http://www.hindawi.com
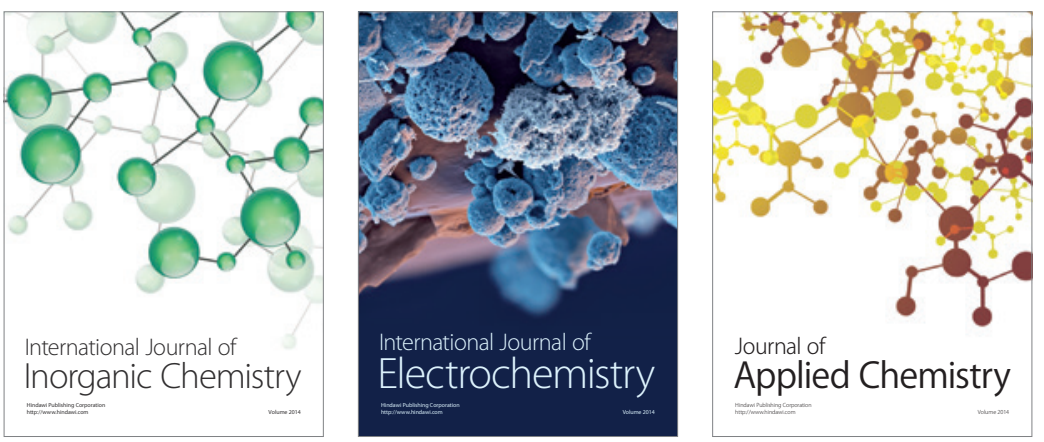

Journal of

Applied Chemistry
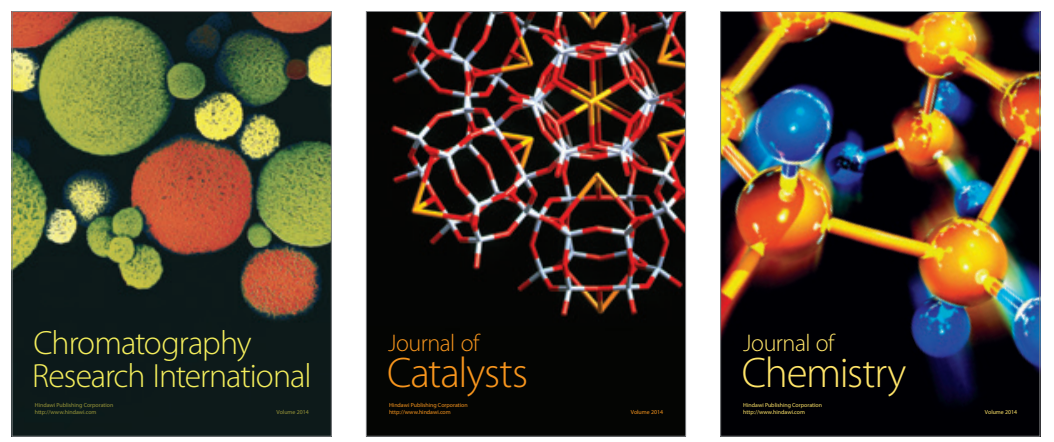
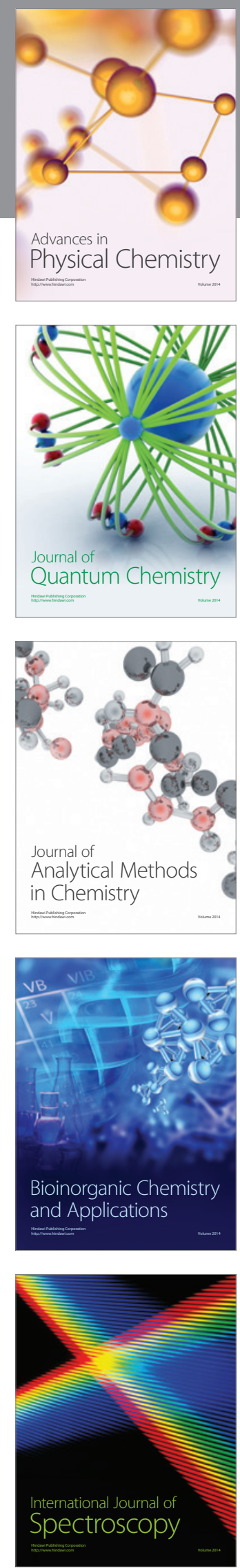